Article

\title{
Quality of New Potatoes (Solanum tuberosum L.) in Response to Plant Biostimulants Application
}

\author{
Wanda Wadas ${ }^{1, *(1)}$ and Tomasz Dziugieł ${ }^{2}$ \\ 1 Institute of Agriculture and Horticulture, Faculty of Agrobioengineering and Animal Husbandry, \\ Siedlce University of Natural Sciences and Humanities, B. Prusa 14, 08-110 Siedlce, Poland \\ 2 Main Inspectorate of Plant Health and Seed Inspection, Voivodeship Plant Health and Seed Inspection \\ Service, Żółkiewskiego 17, 05-075 Warszawa-Wesoła, Poland; tomasz_dziugiel@wp.pl \\ * Correspondence: wanda.wadas@uph.edu.pl
}

Received: 15 May 2020; Accepted: 22 June 2020; Published: 3 July 2020

\begin{abstract}
Background: In sustainable crop production focusing on high-value products, biostimulants have been gaining increasing importance, thus the hypothesis that plant biostimulants could contribute to improving new potatoes quality; Methods: The effects of the seaweed extracts Bio algeen S90 (Ascophyllum nodosum) and Kelpak SL (Ecklonia maxima), as well as the humic and fulvic acids in HumiPlant (leonardite extract) on the tuber quality of very early potato cultivars ('Denar', 'Lord', 'Miłek') were investigated. Potatoes were harvested 75 days after planting (the end of June); Results: The biostimulants did not affect dry matter, protein, total sugars, monosaccharides and sucrose or L-ascorbic acid content in new potatoes. Bio-algeen S90 increased the starch content in tubers of all potato cultivars tested, on average, by $4.8 \mathrm{~g} \cdot \mathrm{kg}^{-1}$ compared with control treatment without biostimulant, whereas Kelpak SL and HumiPlant reduced nitrates content only in tubers of 'Denar' cultivar, on average, by $8.50 \mathrm{mg} \cdot \mathrm{kg}^{-1}$, and increased ascorbate-nitrate index ( $\left.\mathrm{I}_{\mathrm{AN}}\right)$ by 0.29 . The biostimulants did not affect potato after-cooking darkening. Both the nutritional value of new potatoes and after-cooking darkening depended on the cultivar and weather conditions during the potato growing period to a great extent; Conclusions: Plant biostimulants slightly affected quality of new potatoes.
\end{abstract}

Keywords: seaweed extract; humic acids; nutritional value; after-cooking darkening

\section{Introduction}

Potatoes play an important role in the global food security, nutrition and healthy diet [1]. Potatoes provide a significant amount of high-quality protein, vitamin C (mainly L-ascorbic acid) and group B vitamins, minerals as well as other health-promoting compounds. Consumption of $250-300 \mathrm{~g}$ of boiled potatoes provides about $7-8 \%$ of the recommended daily intake of protein, $6-11 \%$ of carbohydrates, $50 \%$ of vitamin C, $30-40 \%$ of potassium and about $17 \%$ of fibre. Apart from nutrients, potato tubers also contain anti-nutritional substances such as nitrates or glycoalkaloids. The quality of edible potatoes is determined by their nutritional value and low content of anti-nutrients. An important quality characteristic is also sensory properties including after-cooking darkening [2-4]. The chemical composition of potato tubers depends on the cultivar, tuber size and maturity, but may change under environmental (weather and soil conditions) and agronomic factors [5-7].

In sustainable crop production focusing on high-value products, biostimulants have been gaining increasing importance. These natural products enhance nutrition efficiency, abiotic stress tolerance and/or crop quality traits. Plant biostimulant based on seaweed extracts and humic acids have the largest market share [8-10]. 
Seaweed extracts are complex mixtures with multiple mechanisms of action. Bioactive compounds present in seaweed extracts improve plant growth, enhance nutrient use efficiency, improve plant defences against pathogens and improve crop quality. The bioactivity of seaweed extracts depend on the algae species and the extraction method. Most commercial seaweed products used as plant biostimulants in agriculture and horticulture are manufactured from brown seaweeds (Phaeophyta). Ascophyllum nodosum (A. nodosum) and Ecklonia maxima (E. maxima) are dominant in this group [11-13]. The A.nodosum extract Bio-algeen S90 and the E. maxima extract Kelpak SL are used worldwide as a biostimulants for a number of agricultural and horticultural crops. Biostimulants based on A. nodosum extracts are used to improwe plant growth and to mitigate abiotic and biotic stresses. The effect of A. nodosum extracts on plants are attributed to phytohormone, microelement, and/or alga-specific polysaccharides, betaines, polyamines and phenolic compounds contents [14,15]. E. maxima extract Kelpak SL contains auxins, cytokinins, polyamines, abscisic acid, gibberellin, brassinosteriods and a small amounts of macro- and microelements. The active compounds present in Kelpak SL, alone or in combination, bring contribute to enhance plant growth and yield, and improve biotic and abiotic stresses tolerance. Content of some active compounds in Kelpak is higher than in other commercial products based on E. maxima extract [16,17]. Commercial seaweed products manufactured from the same seaweed source by different companies, generally marketed as equivalent products, may vary significantly in product composition and in efficacy to induce specific plant responses following appplication, especially under field conditions. Commercial $A$. nodosum extracts Phylgreenmira, Algazone and Ultra-Kelp increased the dry matter and starch content in potato tubers, as well as slightly decreased protein content [18], whereas Bio-algeen S90 did not affect the starch, total nitrogen content or the potato after-cooking darkening $[19,20]$. Other products based on $A$. nodosum extract Primo increased nitrogen and protein content in potato tubers [21]. Bio-algeen S90 did not affect dry matter content in carrot, but increased L-ascorbic acid and total sugar contents [22]. E. maxima extract Kelpak SL did not affect starch or total nitrogen content in potato tubers, but increased vitamin $C$ and nitrate contents $[20,23]$. Kelpak SL increased nitrate and nitrite content in carrot and protein content in beans, decreased starch content in wheat, but did not affect protein or fat content in winter rape [24-27].

The biostimulant effects of humic substances are characterized by both structural and physiological changes in plants related to nutrient uptake, assimilation and distribution, and changes in plant primary and secondary metabolism related to abiotic stress tolerance. The biological activity of humic substances depends on their source, chemical structure, and concentrations. Leonardite is the most common commercial source of humic substances [28-30]. Humic substances extracted from leonardite stimulate plant growth, nitrogen metabolism and accumulation of phenolic compounds. The positive effects of humic substances on plant metabolism are attributed to phytohormone-like activity. Biostimulant activity of humic substances extracted from leonardites depends on the origin of the leonardite [31]. Humic acids derived from leonardite applied to soil or introduced into the irrigation system increased dry matter, starch and protein content in potato tuber [32-34]. Soil application of humic acids did not affect dry matter or starch content in potato tubers, whereas the foliar application of fulvic acids did not affect tuber dry matter but increased starch content [35]. Foliar application of humic and fulvic acids in HumiPlant, a commercial extract from leonardite, increased the sugar and carotenoid contents and decreased the nitrate content in carrot [36]. Soil and foliar application of humic acid increased the sugar content in pepper and cucumber $[37,38]$, whereas foliar application of humic and fulvic acids increased the vitamin $C$ content and reduced tomato acidity [39].

To date, few studies have been focused on the effect of plant biostimulants on potato tuber quality. The current study aimed to determine the effect of foliar application of seaweed extracts and humic and fulvic acids on the quality of new potatoes. In the current study, it was hypothesised that seaweed extracts and humic acids could contribute to improving edible potato quality. 


\section{Materials and Methods}

\subsection{Plant Material and Experimental Design}

The study material included potato tubers obtained from a field experiment carried out in central-eastern Poland $\left(52^{\circ} 03^{\prime} \mathrm{N} ; 2^{\circ} 33^{\prime}\right.$ E) over three growing season, (2012-2014) with different weather conditions (Table 1).

Table 1. Hydrothermal conditions during potato growing period.

\begin{tabular}{|c|c|c|c|c|c|c|c|c|c|c|c|}
\hline \multirow{3}{*}{ Months } & \multicolumn{4}{|c|}{ Average Daily Temperature $\left({ }^{\circ} \mathrm{C}\right)$} & \multicolumn{4}{|c|}{ Rainfall (mm) } & \multirow{2}{*}{\multicolumn{3}{|c|}{ Hydrothermal Index }} \\
\hline & \multirow{2}{*}{$\begin{array}{c}\text { Long-Term } \\
\text { Average } \\
\text { 1981-2010 }\end{array}$} & \multicolumn{3}{|c|}{$\begin{array}{l}\text { Deviation from } \\
\text { Long-Term Average }\end{array}$} & \multirow{2}{*}{$\begin{array}{l}\text { Long-Term } \\
\text { Average } \\
\text { 1981-2010 }\end{array}$} & \multicolumn{3}{|c|}{$\begin{array}{l}\text { Deviation from } \\
\text { Long-Term Average }\end{array}$} & & & \\
\hline & & 2012 & 2013 & 2014 & & 2012 & 2013 & 2014 & 2012 & 2013 & 2014 \\
\hline April & 8.3 & +0.6 & -0.9 & +1.5 & 41.2 & -11.3 & -5.2 & +3.8 & 1.1 & 1.6 & 1.5 \\
\hline May & 12.2 & +2.4 & +3.1 & +1.3 & 53.0 & -0.4 & +52.9 & +39.7 & 1.2 & 2.2 & 2.2 \\
\hline June & 16.8 & -0.8 & +1.2 & -1.4 & 63.8 & +12.4 & +35.0 & -8.4 & 1.5 & 1.8 & 1.2 \\
\hline
\end{tabular}

Hydrothermal index value: up to 0.4 extremely dry; $0.41-0.7$ very dry; $0.71-1.0$ dry; $1.01-1.3$ quite dry;

1.31-1.6 optimal; $1.61-2.0$ quite wet; $2.01-2.5$ wet; $2.51-3.0$ very wet; $>3$ extremely wet [40].

The field experiment was carried out on Luvisol with $\mathrm{pH}$ in $\mathrm{KCl}$ from 4.7 to 6.3. The content of total nitrogen in soil ranged from 7 to $11 \mathrm{mg} \mathrm{N} \cdot \mathrm{kg}^{-1}$, the content of available phosphorus ranged from 118 to $144 \mathrm{mg} \mathrm{P} \cdot \mathrm{kg}^{-1}$, potassium from 124 to $208 \mathrm{mg} \mathrm{K} \cdot \mathrm{kg}^{-1}$ and magnesium from 22 to $51 \mathrm{mg} \mathrm{Mg} \cdot \mathrm{kg}^{-1}$ of soil. The soil chemical properties were determined using soil laboratory procedures at the National Chemical and Agricultural Station: $\mathrm{pH}$ with potentiometric method in $1 \mathrm{~mol} \cdot \mathrm{dm}^{-3} \mathrm{KCl}$ [41], total nitrogen with the Kjeldahl method [42], available forms of phosphorus with spectrophotometric method [43], potassium with the flame atomic emission spectroscopy (FAES) method [44] and magnesium with flame atomic absorption spectroscopy (FAAS) method [45].

The field experiment was established in a split-plot design with three replications. The examined factors were: factor I-plant biostimulant: control without biostimulant, Bio-algeen S90, Kelpak SL and HumiPlant (Table 2), factor II-potato cultivar: 'Denar', 'Lord' and 'Miłek'(Table 3).

Table 2. Characteristics of plant biostimulants; according to manufacturers.

\begin{tabular}{|c|c|}
\hline Plant Biostimulant & Active Compounds \\
\hline $\begin{array}{c}\text { Bio-algeen S90 } \\
\text { Ascophyllum nodosum extract }\end{array}$ & $\begin{array}{l}\text { amino acids, vitamins, alginic acids and other active components } \\
\text { of seaweeds, macronutrients }(\mathrm{N}, \mathrm{P}, \mathrm{K}, \mathrm{Ca}, \mathrm{Mg}) \text { and micronutrients } \\
\qquad(\mathrm{B}, \mathrm{Fe}, \mathrm{Cu}, \mathrm{Mn}, \mathrm{Zn}, \mathrm{Se}, \mathrm{Co})\end{array}$ \\
\hline $\begin{array}{c}\text { Kelpak SL } \\
\text { Ecklonia maxima extract }\end{array}$ & auksin $\left(11 \mathrm{mg} \cdot \mathrm{dm}^{-3}\right)$, cytokinin $\left(0.031 \mathrm{mg} \cdot \mathrm{dm}^{-3}\right)$ \\
\hline HumiPlant leonardite extract & $\begin{array}{c}\text { humic acid (12\%), fulvic acid ( } 6 \%) \text {, macronutrients }(\mathrm{K}, \mathrm{Ca}, \mathrm{Mg}, \mathrm{S}) \\
\text { and micronutrients }(\mathrm{Fe}, \mathrm{Mn}, \mathrm{B}, \mathrm{Mo}, \mathrm{Zn}, \mathrm{Cu})\end{array}$ \\
\hline
\end{tabular}

Table 3. Characteristics of potato cultivars [46].

\begin{tabular}{ccccc}
\hline Cultivar & Country of Origin & Cooking Type & Plants' Soil Requirements & Plants' Water Requirements \\
\hline Denar & Poland & $\mathrm{AB}$ & medium-large & medium-large \\
Lord & Poland & $\mathrm{AB}$ & medium & tolerant \\
Miłek & Poland & $\mathrm{BC}$ & medium & medium-large \\
\hline
\end{tabular}

Cooking type: $\mathrm{AB}-$ multi-purpose type to salad type, $\mathrm{BC}$-multi-purpose type to floury type.

6-weeks pre-sprouted seed potatoes were planted on 12 April 2012, 18 April 2013 and 7 April 2014, with a row spacing of $0.250 \mathrm{~m}$ and $0.675 \mathrm{~m}$ between rows. The plots were six rows wide and $4 \mathrm{~m}$ long (96 plants per plot). Potato cultivation was carried out according to common agronomical practice. 
The biostimulants were applied twice, in one or two-weeks intervals, according to the manufacturers' recommendations: Bio-algeen $S 90$ at the beginning of leaf development stage (according to a uniform coding of phenologically similar growth stages of plant species of Biologische Bundesanstalt, Bundessortenamt and Chemical Industry the BBCH 10-11 stage) and two weeks after the first treatment, Kelpak SL at the leaf development stage (BBCH 14-16) and two weeks after the first treatment, HumiPlant at the leaf of development stage (BBCH 14-16) and one week after the first treatment [47]. In each treatment, the biostimulants were applied at the dose of $2 \mathrm{dm}^{3} \cdot \mathrm{ha}^{-1}$. Potato plants sprayed with water were used as a control without a biostimulant. Due to different active compounds, the application of the tested biostimulants at different time points in the early stages of potato growth ensure better root system development and better the plants growth at later time. Potatoes were harvested 75 days after planting (the end of June).

\subsection{Laboratory Analysis}

Laboratory studies were conducted on samples of 50 different-sized tubers taken from each plot. Fresh potatoes were analysed immediately after sampling.

Potato tubers were analysed for:

- dry matter-with the gravimetric method by drying to the constant weight at $105{ }^{\circ} \mathrm{C}$ [48],

- starch-with the polarimetric method according to Ewers after hydrolyze with $0.1 \mathrm{~N}(0.1 \mathrm{M})$ hydrochloric acid $(\mathrm{HCl})$; the optical rotation was measured at a wavelength of $589 \mathrm{~nm}$ [49],

- total sugars (glucose, fructose and sucrose), monosaccharides (glucose and fructose) and sucrose-with the Luff-Schoorl method after inversion to reducing sugars and reduction, under alkaline medium, cupric $\left(\mathrm{Cu}^{2+}\right)$ ions of copper sulphate $\left(\mathrm{CuSO}_{4}\right)$ to cuprous $\left(\mathrm{Cu}^{+}\right)$oxide $\left(\mathrm{Cu}_{2} \mathrm{O}\right)$; sucrose content was calculated from the difference of the total sugars after inversion and the reducing sugars, using the conversion factor 0.95 [50],

- total protein-with the Kjeldahl method using the conversion factor of total nitrogen to total protein 6.25 [51],

- $\quad$ L-ascorbic acid-with the titration method with 2,6-dichlorophenolindophenol (DCPIP) according to Tillmans after extraction with $2 \%$ oxalic acid $\left(\mathrm{C}_{2} \mathrm{H}_{2} \mathrm{O}_{4} \cdot \mathrm{H}_{2} \mathrm{O}\right)$ [52],

- nitrates-with the spectrophotometric method based on the Griess reaction after reduction of the nitrates to nitrites with cadmium dust; the absorbance was measured at a wavelength of $538 \mathrm{~nm}$ [53].

The results were expressed as grams or milligrams per kilogram of fresh weight (FW) of potatoes. The ascorbate-nitrate index $\left(\mathrm{I}_{\mathrm{AN}}\right)$ was calculated as the ratio of L-ascorbic acid amount-to-nitrate amount in potato tubers [54].

Potato after-cooking darkening was also determined. The assessment of potato after-cooking darkening was performed after $10 \mathrm{~min}$ and $2 \mathrm{~h}$ following boiling in water, using the 9-point Danish scale on which 9 means no darkening and 1 denotes the strongest darkening. The assessment of potato after-cooking darkening was conducted on ten tubers per plot [55].

\subsection{Statistical Analysis}

The results of the three-year study were analysed statistically using a two-factor analysis of variance (ANOVA) for the split-plot design (plant biostimulant $\times$ potato cultivar $\times$ years). The significance of the sources of variability was tested using the Fisher-Snedecor test, and the significance of differences between the compared averages was verified using Tukey's test at the significance level $p \leq 0.05$. Statistical calculations were performed in Excel software using the authors' own algorithm based on the split-plot mathematical model. 


\section{Results}

\subsection{Dry Matter and Carbohydrates Content}

The biostimulants used in the experiment had no effect on dry matter content in tubers (Table 4). The dry matter content in potato tuber depended on the cultivar and weather conditions to a greater extent.

Table 4. Dry matter content in potato tubers; $\mathrm{g} \cdot \mathrm{kg}^{-1} \mathrm{FW}$.

\begin{tabular}{cccccccc}
\hline \multirow{2}{*}{ Plant Biostimulant } & \multicolumn{3}{c}{ Years } & \multicolumn{3}{c}{ Cultivar } & Mean \\
\cline { 2 - 6 } & $\mathbf{2 0 1 2}$ & $\mathbf{2 0 1 3}$ & $\mathbf{2 0 1 4}$ & Denar & Lord & Miłek & \\
\hline Without biostimulant & $168.8 \mathrm{a}$ & $194.4 \mathrm{a}$ & $184.3 \mathrm{a}$ & $179.8 \mathrm{a}$ & $175.0 \mathrm{a}$ & $192.8 \mathrm{a}$ & $182.5 \mathrm{~A}$ \\
Bio-algeen S90 & $166.7 \mathrm{a}$ & $192.0 \mathrm{a}$ & $184.0 \mathrm{a}$ & $177.6 \mathrm{a}$ & $173.7 \mathrm{a}$ & $191.4 \mathrm{a}$ & $180.9 \mathrm{~A}$ \\
Kelpak SL & $165.7 \mathrm{a}$ & $188.0 \mathrm{a}$ & $188.7 \mathrm{a}$ & $174.9 \mathrm{a}$ & $178.0 \mathrm{a}$ & $189.6 \mathrm{a}$ & $180.8 \mathrm{~A}$ \\
HumiPlant & $168.7 \mathrm{a}$ & $197.9 \mathrm{a}$ & $184.4 \mathrm{a}$ & $174.2 \mathrm{a}$ & $179.6 \mathrm{a}$ & $197.2 \mathrm{a}$ & $183.7 \mathrm{~A}$ \\
\hline Mean & $167.5 \mathrm{~B}$ & $193.1 \mathrm{~A}$ & $185.4 \mathrm{~A}$ & $176.6 \mathrm{~B}$ & $176.6 \mathrm{~B}$ & $192.7 \mathrm{~A}$ & 182.0 \\
\hline
\end{tabular}

Means within columns/rows followed by the same lowercase/uppercase letters do not differ significantly at $p \leq 0.05$. Means in columns marked with lowercase refer to interactions: plant biostimulant $\times$ years, plant biostimulant $\times$ cultivar. Means in the last column and means in the last row marked with uppercase are for plant biostimulants, years and cultivars.

Regardless of the treatment (with or without biostimulant), tubers of 'Miłek' contained more dry matter than 'Denar' and 'Lord'. The most dry matter was accumulated by potato tubers in the warm and moist growing season of 2013. The plant biostimulant and potato cultivar interaction effect on the dry matter content in tubers was not found.

The plant biostimulant had a significant effect on starch content but did not affect the content of total sugars (glucose, fructose and sucrose), monosaccharides (glucose and fructose) or sucrose (Table 5).

Table 5. Carbohydrates content in potato tubers.

\begin{tabular}{|c|c|c|c|c|c|c|c|}
\hline \multirow{2}{*}{ Plant Biostimulant } & \multicolumn{3}{|c|}{ Years } & \multicolumn{3}{|c|}{ Cultivar } & \multirow{2}{*}{ Mean } \\
\hline & 2012 & 2013 & 2014 & Denar & Lord & Miłek & \\
\hline \multicolumn{8}{|c|}{ Starch $\left(\mathrm{g} \cdot \mathrm{kg}^{-1} \mathrm{FW}\right)$} \\
\hline Without biostimulant & $119.0 \mathrm{a}$ & $130.4 \mathrm{a}$ & $98.1 \mathrm{~b}$ & $108.3 \mathrm{a}$ & $115.7 \mathrm{a}$ & $123.5 \mathrm{a}$ & $115.9 \mathrm{~B}$ \\
\hline Bio-algeen S90 & $119.1 \mathrm{a}$ & $133.2 \mathrm{a}$ & $109.8 \mathrm{a}$ & 113.6 a & $116.1 \mathrm{a}$ & $132.4 \mathrm{a}$ & $120.7 \mathrm{~A}$ \\
\hline Kelpak SL & $119.3 \mathrm{a}$ & $134.3 \mathrm{a}$ & $97.0 \mathrm{~b}$ & $112.8 \mathrm{a}$ & $113.0 \mathrm{a}$ & $124.9 \mathrm{a}$ & $116.9 \mathrm{~B}$ \\
\hline HumiPlant & $120.8 \mathrm{a}$ & $133.8 \mathrm{a}$ & $97.2 \mathrm{~b}$ & $113.3 \mathrm{a}$ & $114.6 \mathrm{a}$ & $123.9 \mathrm{a}$ & $117.3 \mathrm{AB}$ \\
\hline Mean & $119.6 \mathrm{~B}$ & $132.9 \mathrm{~A}$ & $100.5 \mathrm{~B}$ & $112.0 \mathrm{C}$ & $114.8 \mathrm{~B}$ & $126.2 \mathrm{~A}$ & 117.7 \\
\hline \multicolumn{8}{|c|}{ Total sugars $\left(\mathrm{g} \cdot \mathrm{kg}^{-1} \mathrm{FW}\right)$} \\
\hline Without biostimulant & $7.92 \mathrm{a}$ & $8.13 \mathrm{a}$ & $6.30 \mathrm{a}$ & $7.32 \mathrm{a}$ & $7.28 \mathrm{a}$ & $7.76 \mathrm{a}$ & $7.45 \mathrm{~A}$ \\
\hline Bio-algeen S90 & $8.44 \mathrm{a}$ & $7.68 \mathrm{a}$ & $6.18 \mathrm{a}$ & $7.38 \mathrm{a}$ & $7.40 \mathrm{a}$ & $7.52 \mathrm{a}$ & $7.43 \mathrm{~A}$ \\
\hline Kelpak SL & $7.58 \mathrm{a}$ & $8.21 \mathrm{a}$ & $6.40 \mathrm{a}$ & $7.24 \mathrm{a}$ & $7.37 \mathrm{a}$ & $7.58 \mathrm{a}$ & $7.40 \mathrm{~A}$ \\
\hline HumiPlant & $7.41 \mathrm{a}$ & $7.99 \mathrm{a}$ & $6.18 \mathrm{a}$ & $7.14 \mathrm{a}$ & $7.30 \mathrm{a}$ & $7.13 \mathrm{a}$ & $7.19 \mathrm{~A}$ \\
\hline Mean & $7.84 \mathrm{~A}$ & $8.00 \mathrm{~A}$ & $6.26 \mathrm{~B}$ & $7.27 \mathrm{~A}$ & $7.34 \mathrm{~A}$ & $7.50 \mathrm{~A}$ & 7.37 \\
\hline \multicolumn{8}{|c|}{ Monosaccharides $\left(\mathrm{g} \cdot \mathrm{kg}^{-1} \mathrm{FW}\right)$} \\
\hline Without biostimulant & $2.39 \mathrm{a}$ & $2.36 \mathrm{a}$ & $2.40 \mathrm{a}$ & $2.17 \mathrm{a}$ & $2.38 \mathrm{a}$ & $2.60 \mathrm{a}$ & $2.38 \mathrm{~A}$ \\
\hline Bio-algeen S90 & $2.47 \mathrm{a}$ & $2.27 \mathrm{a}$ & $2.17 \mathrm{a}$ & $2.31 \mathrm{a}$ & $2.32 \mathrm{a}$ & $2.27 \mathrm{a}$ & $2.30 \mathrm{~A}$ \\
\hline Kelpak SL & $2.29 \mathrm{a}$ & $2.63 \mathrm{a}$ & $2.23 \mathrm{a}$ & $2.37 \mathrm{a}$ & $2.36 \mathrm{a}$ & $2.43 \mathrm{a}$ & $2.39 \mathrm{~A}$ \\
\hline HumiPlant & $2.24 \mathrm{a}$ & $2.22 \mathrm{a}$ & $2.38 \mathrm{a}$ & $2.33 \mathrm{a}$ & $2.09 \mathrm{a}$ & $2.32 \mathrm{a}$ & $2.25 \mathrm{~A}$ \\
\hline Mean & $2.35 \mathrm{~A}$ & $2.37 \mathrm{~A}$ & $2.27 \mathrm{~A}$ & $2.29 \mathrm{~A}$ & $2.29 \mathrm{~A}$ & $2.41 \mathrm{~A}$ & 2.33 \\
\hline
\end{tabular}


Table 5. Cont.

\begin{tabular}{|c|c|c|c|c|c|c|c|}
\hline \multirow{2}{*}{ Plant Biostimulant } & \multicolumn{3}{|c|}{ Years } & \multicolumn{3}{|c|}{ Cultivar } & \multirow{2}{*}{ Mean } \\
\hline & 2012 & 2013 & 2014 & Denar & Lord & Miłek & \\
\hline \multicolumn{8}{|c|}{ Sucrose $\left(\mathrm{g} \cdot \mathrm{kg}^{-1} \mathrm{FW}\right)$} \\
\hline Without biostimulant & $5.26 \mathrm{a}$ & $5.29 \mathrm{a}$ & $3.70 \mathrm{a}$ & $4.80 \mathrm{a}$ & $4.66 \mathrm{a}$ & $4.79 \mathrm{a}$ & $4.75 \mathrm{~A}$ \\
\hline Bio-algeen S90 & $5.68 \mathrm{a}$ & $5.14 \mathrm{a}$ & $3.81 \mathrm{a}$ & $4.81 \mathrm{a}$ & $4.82 \mathrm{a}$ & $4.99 \mathrm{a}$ & $4.88 \mathrm{~A}$ \\
\hline Kelpak SL & $5.02 \mathrm{a}$ & $5.30 \mathrm{a}$ & $3.96 \mathrm{a}$ & $4.63 \mathrm{a}$ & $4.76 \mathrm{a}$ & $4.89 \mathrm{a}$ & $4.76 \mathrm{~A}$ \\
\hline HumiPlant & $4.91 \mathrm{a}$ & $5.48 \mathrm{a}$ & $3.72 \mathrm{a}$ & $4.58 \mathrm{a}$ & $4.95 \mathrm{a}$ & $4.57 \mathrm{a}$ & $4.70 \mathrm{~A}$ \\
\hline Mean & $5.22 \mathrm{~A}$ & $5.30 \mathrm{~A}$ & $3.80 \mathrm{~B}$ & $4.71 \mathrm{~A}$ & $4.80 \mathrm{~A}$ & $4.81 \mathrm{~A}$ & 4.77 \\
\hline
\end{tabular}

Following the application of Bio-algeen S90, the starch content was higher, on average, by $4.8 \mathrm{~g} \cdot \mathrm{kg}^{-1} \mathrm{FW}$, compared with the control treatment without biostimulant. The greatest difference was found in the year with the lowest air temperature and a drought in the tuber growth period. In that year (2014), following the Bio-algeen S90 application, the starch content was higher by $11.7 \mathrm{~g} \cdot \mathrm{kg}^{-1} \mathrm{FW}$, compared with the control treatment without biostimulant. The plant biostimulant and potato cultivar interaction effect on the starch and sugars content in tubers were not found.

The starch and sugars content in potato tuber depended on the cultivar and weather conditions to a greater extent (Table 5). Regardless of the treatment (with or without biostimulant), tubers of 'Miłek' contained more starch than 'Denar' and 'Lord' whereas the content of total sugars, monosaccharides and sucrose in tubers of the potato cultivars tested were similar. The ratio of starch-to-sugars amounted, on average, 15.5/1 for 'Denar' and 'Lord', and 16.8/1 for 'Miłek', whereas the ratio of sucrose-to-monosaccharides for the potato cultivars tested amounted 2.1/1, on average. The most starch were accumulated by potato tubers in the warm and quite wet growing season of 2013, whereas the least total sugars were accumulated in tubers in 2014, with the lowest air temperature and with a drought periods during tuber growth.

\subsection{Protein Content}

The biostimulants used in the experiment had no effect on protein content in tubers (Table 6). The protein content in potato tuber depended on the cultivar and weather conditions during the potato growing period to a greater extent.

Table 6. Protein content in potato tubers; $\mathrm{g} \cdot \mathrm{kg}^{-1} \mathrm{FW}$.

\begin{tabular}{cccccccc}
\hline \multirow{2}{*}{ Plant Biostimulant } & \multicolumn{3}{c}{ Years } & \multicolumn{3}{c}{ Cultivar } & Mean \\
\cline { 2 - 6 } & $\mathbf{2 0 1 2}$ & $\mathbf{2 0 1 3}$ & $\mathbf{2 0 1 4}$ & Denar & Lord & Miłek & \\
\hline Without biostimulant & $13.70 \mathrm{a}$ & $16.04 \mathrm{a}$ & $14.33 \mathrm{a}$ & $14.36 \mathrm{a}$ & $14.24 \mathrm{a}$ & $15.48 \mathrm{a}$ & $14.69 \mathrm{~A}$ \\
Bio-algeen S90 & $13.31 \mathrm{a}$ & $15.42 \mathrm{a}$ & $14.09 \mathrm{a}$ & $13.57 \mathrm{a}$ & $13.81 \mathrm{a}$ & $15.44 \mathrm{a}$ & $14.27 \mathrm{~A}$ \\
Kelpak SL & $13.28 \mathrm{a}$ & $14.87 \mathrm{a}$ & $14.29 \mathrm{a}$ & $13.64 \mathrm{a}$ & $14.41 \mathrm{a}$ & $14.38 \mathrm{a}$ & $14.14 \mathrm{~A}$ \\
HumiPlant & $14.20 \mathrm{a}$ & $15.84 \mathrm{a}$ & $14.13 \mathrm{a}$ & $13.98 \mathrm{a}$ & $14.47 \mathrm{a}$ & $15.74 \mathrm{a}$ & $14.73 \mathrm{~A}$ \\
\hline Mean & $13.62 \mathrm{~B}$ & $15.54 \mathrm{~A}$ & $14.21 \mathrm{~B}$ & $13.88 \mathrm{~B}$ & $14.23 \mathrm{~B}$ & $15.26 \mathrm{~A}$ & 14.46 \\
\hline
\end{tabular}

Means within columns/rows followed by the same lowercase/uppercase letters do not differ significantly at $p \leq 0.05$. Means in columns marked with lowercase refer to interactions: plant biostimulant $\times$ years, plant biostimulant $\times$ cultivar. Means in the last column and means in the last row marked with uppercase are for plant biostimulants, years and cultivars.

Regardless of the treatment (with or without biostimulant), tubers of 'Miłek' contained more protein than 'Denar' and 'Lord'. The most protein was accumulated by potato tubers in the warm 
and moist growing season of 2013 (Table 6). The plant biostimulant and potato cultivar interaction effect on the protein content in tubers was not found.

\subsection{L-ascorbic Acid and Nitrates Content}

The biostimulants used in the experiment had no effect on L-ascorbic acid or nitrate content in tubers (Table 7). Following the biostimulant application, there was only a slight increase in the L-ascorbic acid content and a slight decrease in the nitrate content. The differences were not statistically confirmed.

Table 7. L-ascorbic acid and nitrates content in potato tubers.

\begin{tabular}{|c|c|c|c|c|c|c|c|}
\hline \multirow{2}{*}{ Plant Biostimulant } & \multicolumn{3}{|c|}{ Years } & \multicolumn{3}{|c|}{ Cultivar } & \multirow{2}{*}{ Mean } \\
\hline & 2012 & 2013 & 2014 & Denar & Lord & Miłek & \\
\hline \multicolumn{8}{|c|}{ L-ascorbic acid (mg.kg $\left.{ }^{-1} \mathrm{FW}\right)$} \\
\hline Without biostimulant & $126.3 \mathrm{a}$ & 126.7 a & $117.2 \mathrm{a}$ & $123.2 \mathrm{a}$ & 125.7 a & $121.3 \mathrm{a}$ & $123.4 \mathrm{~A}$ \\
\hline Bio-algeen S90 & $130.3 \mathrm{a}$ & $129.8 \mathrm{a}$ & $114.6 \mathrm{a}$ & $124.7 \mathrm{a}$ & $123.9 \mathrm{a}$ & $126.1 \mathrm{a}$ & $124.9 \mathrm{~A}$ \\
\hline Kelpak SL & 130.9 a & $127.6 \mathrm{a}$ & $119.0 \mathrm{a}$ & 129.7 a & $125.4 \mathrm{a}$ & $122.3 \mathrm{a}$ & $125.8 \mathrm{~A}$ \\
\hline HumiPlant & $125.8 \mathrm{a}$ & 128.3 a & $124.6 \mathrm{a}$ & $128.8 \mathrm{a}$ & $127.0 \mathrm{a}$ & 122.9 a & $126.2 \mathrm{~A}$ \\
\hline Mean & $128.3 \mathrm{~A}$ & $128.1 \mathrm{~A}$ & 118.8 B & $126.6 \mathrm{~A}$ & $125.5 \mathrm{~A}$ & $123.2 \mathrm{~A}$ & 125.1 \\
\hline \multicolumn{8}{|c|}{ Nitrates $\left(\mathrm{mg} \cdot \mathrm{kg}^{-1} \mathrm{FW}\right)$} \\
\hline Without biostimulant & 69.78 a & $71.44 \mathrm{a}$ & 69.67 & $73.22 \mathrm{a}$ & $65.56 \mathrm{a}$ & $72.11 \mathrm{a}$ & $70.30 \mathrm{~A}$ \\
\hline Bio-algeen S90 & 66.56 a & $68.44 \mathrm{a}$ & 66.44 & $68.56 \mathrm{ab}$ & 58.33 a & $74.56 \mathrm{a}$ & $67.15 \mathrm{~A}$ \\
\hline Kelpak SL & $67.89 \mathrm{a}$ & $66.78 \mathrm{a}$ & 66.78 & $64.78 \mathrm{~b}$ & $65.33 a$ & $71.33 \mathrm{a}$ & $67.15 \mathrm{~A}$ \\
\hline HumiPlant & $70.44 \mathrm{a}$ & $68.56 \mathrm{a}$ & 66.22 & $64.67 \mathrm{~b}$ & $65.00 \mathrm{a}$ & $75.56 \mathrm{a}$ & $68.41 \mathrm{~A}$ \\
\hline Mean & $68.67 \mathrm{~A}$ & $68.81 \mathrm{~A}$ & $67.28 \mathrm{~A}$ & $67.81 \mathrm{~B}$ & $63.56 \mathrm{~B}$ & $73.39 \mathrm{~A}$ & 68.25 \\
\hline \multicolumn{8}{|c|}{ Ascorbate-nitrate index $\left(\mathrm{I}_{\mathrm{AN}}\right)$} \\
\hline Without biostimulant & $1.82 \mathrm{a}$ & $1.79 \mathrm{a}$ & $1.74 \mathrm{a}$ & $1.71 \mathrm{~b}$ & $1.95 \mathrm{a}$ & $1.70 \mathrm{a}$ & $1.78 \mathrm{~A}$ \\
\hline Bio-algeen S90 & $1.99 \mathrm{a}$ & $1.93 \mathrm{a}$ & $1.78 \mathrm{a}$ & $1.85 \mathrm{ab}$ & $2.14 \mathrm{a}$ & $1.71 \mathrm{a}$ & $1.90 \mathrm{~A}$ \\
\hline Kelpak SL & $1.95 \mathrm{a}$ & $1.92 \mathrm{a}$ & $1.79 \mathrm{a}$ & $2.01 \mathrm{a}$ & $1.93 \mathrm{a}$ & $1.72 \mathrm{a}$ & $1.89 \mathrm{~A}$ \\
\hline HumiPlant & $1.82 \mathrm{a}$ & $1.88 \mathrm{a}$ & $1.90 \mathrm{a}$ & $2.00 \mathrm{a}$ & $1.96 \mathrm{a}$ & $1.63 \mathrm{a}$ & $1.86 \mathrm{~A}$ \\
\hline Mean & $1.89 \mathrm{~A}$ & $1.88 \mathrm{~A}$ & $1.80 \mathrm{~B}$ & $1.89 \mathrm{AB}$ & $2.00 \mathrm{~A}$ & $1.71 \mathrm{~B}$ & 1.86 \\
\hline
\end{tabular}

Means within columns/rows followed by the same lowercase/uppercase letters do not differ significantly at $p \leq 0.05$. Means in columns marked with lowercase refer to interactions: plant biostimulant $\times$ years, plant biostimulant $\times$ cultivar. Means in the last column and means in the last row marked with uppercase are for plant biostimulants, years and cultivars.

The plant biostimulant and potato cultivar interaction effect on the L-ascorbic acid content in tubers was not found (Table 7). The plant biostimulant applied had a greater effect on the nitrate content of 'Denar' than 'Lord' and 'Miłek'. Following the application of Kelpak SL and HumiPlant, the nitrate contents in the tubers of 'Denar' were lower, on average, by $8.50 \mathrm{mg} \cdot \mathrm{kg}^{-1} \mathrm{FW}$, compared with the control treatment without biostimulant, while the ratio of L-ascorbic acid amount-to-nitrate amount in tubers $\left(\mathrm{I}_{\mathrm{AN}}\right)$ was higher by 0.29 .

Regardless of the plant biostimulant applied, tubers of the tested potato cultivars had similar L-ascorbic acid, but 'Miłek' accumulated the most nitrates (Table 7). The I $\mathrm{AN}_{\mathrm{AN}}$ value for 'Miłek' tubers was 0.29 lower than for 'Lord', on average, and was 0.18 lower compared to 'Denar'. The lowest L-ascorbic acid was accumulated by potato tubers in the year with the lowest air temperature and a moisture shortage in the tuber growth period (2014). The weather conditions during the potato growing period had no effect on the nitrate accumulation in potato tubers. 


\subsection{Potato After-Cooking Darkening}

Biostimulants did not affect the potato after-cooking darkening (Table 8). This quality characteristic of edible potatoes depended to a greater extent on the cultivar and weather conditions during the potato growing season.

Table 8. Potato after-cooking darkening.

\begin{tabular}{cccccccc}
\hline \multirow{2}{*}{ Plant Biostimulant } & \multicolumn{5}{c}{ Cultivar } & \multirow{2}{*}{ Mean } \\
\cline { 2 - 6 } & $\mathbf{2 0 1 2}$ & $\mathbf{2 0 1 3}$ & $\mathbf{2 0 1 4}$ & Denar & Lord & Miłek \\
\hline Without biostimulant & $8.72 \mathrm{a}$ & $8.94 \mathrm{a}$ & $8.94 \mathrm{a}$ & $8.94 \mathrm{a}$ & $9.00 \mathrm{a}$ & $8.67 \mathrm{a}$ & $8.87 \mathrm{~A}$ \\
Bio-algeen S90 & $8.72 \mathrm{a}$ & $8.89 \mathrm{a}$ & $9.00 \mathrm{a}$ & $8.94 \mathrm{a}$ & $8.94 \mathrm{a}$ & $8.72 \mathrm{a}$ & $8.87 \mathrm{~A}$ \\
Kelpak SL & $8.89 \mathrm{a}$ & $8.83 \mathrm{a}$ & $9.00 \mathrm{a}$ & $8.94 \mathrm{a}$ & $8.94 \mathrm{a}$ & $8.83 \mathrm{a}$ & $8.91 \mathrm{~A}$ \\
HumiPlant & $9.00 \mathrm{a}$ & $8.83 \mathrm{a}$ & $9.00 \mathrm{a}$ & $8.94 \mathrm{a}$ & $9.00 \mathrm{a}$ & $8.89 \mathrm{a}$ & $8.94 \mathrm{~A}$ \\
\hline Mean & $8.83 \mathrm{~B}$ & $8.88 \mathrm{AB}$ & $8.99 \mathrm{~A}$ & $8.94 \mathrm{~A}$ & $8.97 \mathrm{~A}$ & $8.78 \mathrm{~B}$ & 8.90 \\
\hline \multicolumn{2}{c}{$2 \mathrm{~h}$ after cooking $(9-$-point Danish scale) } & & & $8.78 \mathrm{~A}$ \\
\hline Without biostimulant & $8.61 \mathrm{a}$ & $8.89 \mathrm{a}$ & $8.83 \mathrm{a}$ & $8.89 \mathrm{a}$ & $8.89 \mathrm{a}$ & $8.56 \mathrm{a}$ & $8.68 \mathrm{~A}$ \\
Bio-algeen S90 & $8.61 \mathrm{a}$ & $8.61 \mathrm{a}$ & $8.83 \mathrm{a}$ & $8.83 \mathrm{a}$ & $8.78 \mathrm{a}$ & $8.44 \mathrm{a}$ & $8.72 \mathrm{~A}$ \\
Kelpak SL & $8.78 \mathrm{a}$ & $8.61 \mathrm{a}$ & $8.78 \mathrm{a}$ & $8.83 \mathrm{a}$ & $8.72 \mathrm{a}$ & $8.61 \mathrm{a}$ & $8.82 \mathrm{~A}$ \\
HumiPlant & $8.83 \mathrm{a}$ & $8.72 \mathrm{a}$ & $8.89 \mathrm{a}$ & $8.89 \mathrm{a}$ & $8.89 \mathrm{a}$ & $8.67 \mathrm{a}$ & 8.75 \\
\hline Mean & $8.71 \mathrm{~A}$ & $8.71 \mathrm{~A}$ & $8.83 \mathrm{~A}$ & $8.86 \mathrm{~A}$ & $8.82 \mathrm{~A}$ & $8.57 \mathrm{~B}$ & 8.75 \\
\hline
\end{tabular}

Means within columns/rows followed by the same lowercase/uppercase letters do not differ significantly at $p \leq 0.05$. Means in columns marked with lowercase refer to interactions: plant biostimulant $\times$ years, plant biostimulant $\times$ cultivar. Means in the last column and means in the last row marked with uppercase are for plant biostimulants, years and cultivars.

'Miłek' tubers showed greater susceptibility to darkening, both directly after cooking and two hours after cooking. The greatest potato susceptibility to after-cooking darkening, especially directly after cooking, was observed in the warm and moderately wet growing season of 2012. The plant biostimulant and cultivar interaction effect on the potato after-cooking darkening was not found.

\section{Discussion}

The biostimulants used in the experiment slightly affected potato tuber quality. The dry matter content is one of the most important characteristics of new potatoes. When potatoes are harvested early, low dry matter content can result in a soggy texture and decrease the quality of new potatoes. The biostimulants used in the experiment had no effect on dry matter content in immature tubers of very early potato cultivars 'Denar', 'Lord' and 'Miłek'. In a study carried out by other authors, the biostimulants based on A. nodosum extracts (Phylgreenmira, Algazone, Ultra-Kelp) increased dry matter content in mature tubers of early ('Arizona', 'Riviera') and medium-early ('Agria') potato cultivars [18]. In a previous research, foliar application of fulvic acids had no effect on tuber dry matter of medium-early cultivar 'Atlantic' [35]. The dry matter content in potato tuber is determined by leaf assimilation area and chlorophyll content in leaves. Reducing the assimilation area along with increasing the chlorophyll $a$ content and simultaneously decreasing the chlorophyll $b$ content in leaves increased the dry matter content in tubers [56]. The biostimulants used in the experiment enlarged the assimilation area of very early potato cultivars, but did not affect the chlorophyll content in leaves [57].

The quality of edible potatoes is determined by their starch and sugar contents [4]. Among the biostimulants used in the experiment, only Bio-algeen $\mathrm{S} 90$ (A. nodosum extract) increased starch content in tubers of very early potato cultivars 75 days after planting, especially in a year with a low air temperature and a drought in the tuber growth period. In the three years of the study, following application of this biostimulant, the average starch content was higher by $4.8 \mathrm{~g} \cdot \mathrm{kg}^{-1} \mathrm{FW}$ compared to the average for the untreated control tubers. Bio-algeen $\mathrm{S} 90$ has more bioactive compounds that 
may promote starch synthesis through the induction of carbon metabolism and activities of starch synthesis enzymes. In a study carried out by other authors, Bio-algeen 590 did not affect the starch content in tubers of the medium-early cultivar 'Muza' [19]. Other biostimulants based on A. nodosum extracts (Phylgreenmira, Algazone, Ultra-Kelp) increased starch content in tubers of early ('Arizona', 'Riviera') and medium-early ('Agria') potato cultivars [18]. The bioactivity of seaweed extracts depends on the extraction method [11,12] and on the date and dose of application [13,21]. In the present study, humic and fulvic acids from leonardite in HumiPlant (fulvic acid $6 \%$ and humic acid 12\%) did not affect starch content in immature tubers of very early potato cultivars. In a study carried out by other authors, humic acid from leonardite in Huma K (humic acid 56\% and fulvic acid 30\%) introduced into the irrigation system increased starch content in tubers of medium-early cultivar 'Hermes' [33], and soil application of crude humic acids from leonardite in Agro-Lig (total humic acid 85\%) increased starch content in tubers of late maturity cultivar 'Caspar' [34]. Foliar application of Natural Canadian fulvic acids ( $80 \%$ liquid) increased starch content in tubers of the late cultivar 'Atlantic' [35]. Humic substances affect the activity of the main enzymes involved in carbohydrate metabolism and ADP-glucose pyrophosphorylase (AGPase) has a major role in starch synthesis. The effect of humic substances on enzyme activities depends on humic molecular size, molecular characteristics and concentration [28,31]. The biostimulants used in the experiment did not affect the sugar content in immature tubers of very early potato cultivars. Starch content in potato tubers is associated with assimilation leaf area, the chlorophyll $a$ content in leaves and efficiency of the photosystem in the dark, whereas the sugars content depend on chlorophyll content in leaves and fluorescence yield [56]. The biostimulants used in the experiment did not affect starch and sugar content in immature tubers of very early potato cultivars, except for Bio-algeen S90, although it enlarged the assimilation leaf area [57].

Protein and vitamin $C$ are very important nutritional compounds in potatoes. The protein present in potato tubers has a higher biological value than other crops due to the content of all exogenous amino acids, and especially a high content of lysine [4]. The biostimulants used in the experiment did not affect protein or L-ascorbic acid content in immature tubers of very early potato cultivars. Protein accumulation in potato tuber is determined by leaf assimilation area and the chlorophyll $a$ content in leaves, while vitamin C content is only determined by chlorophyll $a$ content [56]. In the present study, enlargement of the leaf assimilation area as a result of biostimulant application [57] had no effect on the protein content in tubers. In a study carried out by other authors, Bio-algeen S90 and Kelpak SL also did not affect total nitrogen content in tubers of very early ('Volumia') or medium-early ('Irga', 'Satina', 'Silvana') cultivars [20], but Kelpak SL increased the vitamin C content in tubers of a medium-late cultivar ('Bryza') [23].

Although potato tubers accumulate small amounts of nitrates [4], due to high potato consumption they can be a source of substantial quantities of these compounds in the human diet. Nitrates are accumulated in potato tubers when their uptake is greater than the possibility of the plant to utilise them in organic nitrogenous compounds. In general, immaturity in potato tubers has been connected with high nitrate levels. The later the potatoes are harvested, the lower the nitrate contents are in tubers, but the relationship between nitrate content and tuber maturity differs between genotypes [58]. Bio-algeen S90 did not affect nitrate content in immature tubers of very early potato cultivars tested, whereas Kelpak SL and HumiPlant reduced the nitrate content only in tubers of the 'Denar' cultivar. Following the application of those biostimulants, the nitrate content in tubers of 'Denar' was lower, on average, by $8.50 \mathrm{mg} \cdot \mathrm{kg}^{-1} \mathrm{FW}$. In a study carried out by other authors, Bio-algeen $\mathrm{S} 90$ had no effect on nitrate content in tubers of very early ('Volumia') and medium-early ('Irga', 'Satina', 'Silvana') cultivars, whereas Kelpak SL increased the content of these compounds [20]. Seaweed extracts and humic substances may promote nitrogen metabolism. A positive dose-dependent effect of seaweed extracts and humic acids on the activities of the main enzymes involved in the reduction and assimilation of inorganic nitrogen (nitrate reductase, glutamate dehydrogenase and glutamine synthetase) was found $[12,29]$. Results of the present study suggest, that after the application of biostimulants, 
the amount of transcripts of regulatory of enzymes related to the nitrogen metabolism of Denar cultivar increased more than of Lord and Miłek cultivars.

There is a significant correlation between the vitamin $C$ content and nitrate level in potato tubers. A higher content of vitamin $C$ is accompanied by a lower nitrate content [59]. The relative levels of ascorbic acid content and nitrate content in potato tubers may be expressed using the ascorbate-nitrate index $\left(\mathrm{I}_{\mathrm{AN}}\right)$, which is one of the indicators of food safety. A higher index value reflected higher food safety [54]. The biostimulants used in the experiment had no effect on the ratio of L-ascorbic acid amount-to-nitrate amount in tubers of 'Lord' and 'Miłek' cultivars, whereas Kelpak SL and HumiPlant increased this ratio in tubers of the 'Denar' cultivar, on average, by 0.29. Regardless of the treatment (with or without biostimulant), the ratio of L-ascorbic acid amount-to-nitrate amount $\left(\mathrm{I}_{\mathrm{AN}}\right)$ in immature tubers of potato cultivars tested was about $2 / 1$, which indicates that the new potatoes were safe for human health regarding the nitrate content [54].

After-cooking darkening is an important quality characteristic of edible potatoes. It is caused by non-enzymatic oxidation of the chlorogenic acid-iron compound after cooking. The severity of the darkening depends on the ratio of chlorogenic acid-to-citric acid concentration in the potato tubers [60]. The biostimulants used in the experiment did not affect the susceptibility of new potatoes to after-cooking darkening. This characteristics of table potato quality depends on the cultivar [60], which was confirmed in the present study. In a study carried by other authors, Bio-algeen S90 did not affect after-cooking darkening of the 'Muza' medium-early cultivar [19].

The nutrient content in potatoes depends on several factors, with cultivar being among the most important [3]. The nutrient content in potatoes depends on the cultivar and weather conditions during potato growth, to a greater extent than on the biostimulants applied, which was confirmed in a study carried out by other authors [20].

The results of our study showed, that the application of plant biostimulants Bio-algeen S90, Kelpak SL or HumiPlant improved the plant growth and early crop potato yield $[57,61]$ without any negative effect on the nutritional value of new potatoes.

\section{Conclusions}

The foliar application of seaweed extracts A. nodosum (Bio-algeen S90) and E. maxima (Kielpak SL), as well as humic and fulvic acids from leonardite (HumiPlant), did not affect dry matter, protein, total sugars, monosaccharides and sucrose or L-ascorbic acid content in tubers of very early potato cultivars 75 days after planting. Bio-algeen $\mathrm{S} 90$ increased starch content in tubers of all tested potato cultivars, on average, by $4.8 \mathrm{~g} \cdot \mathrm{kg}^{-1} \mathrm{FW}$ compared with control treatment without biostimulant, whereas Kelpak SL and HumiPlant reduced the nitrate content only in tubers of the 'Denar' cultivar, on average, by $8.50 \mathrm{mg} \cdot \mathrm{kg}^{-1} \mathrm{FW}$, and increased $\mathrm{I}_{\mathrm{AN}}$ by 0.29 . The biostimulants did not affect potato after-cooking darkening. The nutritional value of new potatoes and after-cooking darkening depends to a greater extent on the cultivar and weather conditions.

Author Contributions: Conceptualization, W.W. and T.D.; methodology and formal analysis, W.W.; investigation, W.W. and T.D.; writing - original draft preparation, W.W. and T.D.; writing-review and editing, W.W. All authors have read and agreed to the published version of the manuscript.

Funding: This research was financed from the science grant granted by the Polish Ministry of Science and Higher Education, research theme number 218/05/S.

Conflicts of Interest: The authors declare no conflict of interest.

\section{References}

1. Wijesinha-Bettoni, R.; Mouillé, B. The contribution of potatoes to global food security, nutrition and healthy diets. Am. J. Potato Res. 2019, 96, 139-149. [CrossRef]

2. Gupta, U.C.; Gupta, S.C. The important role of potatoes, an underrated vegetable food crop in human health and nutrition. Curr. Nutr. Food Sci. 2019, 15, 11-19. [CrossRef] 
3. Burlingame, B.; Mouillé, B.; Charrondiére, R. Nutrients, bioactive non-nutrients and antinutrients in potatoes. J. Food Compost. Anal. 2009, 22, 494-502. [CrossRef]

4. Lisińska, G.; Peksa, A.; Kita, A.; Rytel, E.; Tajner-Czopek, A. The quality of potato for processing and consumption. Food 2009, 3, 99-104.

5. Ierna, A.; Melilli, M.G. Ascorbic acid and total phenolic content in early potatoes as affected by growing season, genotype and harvest time. Acta Hort. (ISHS) 2014, 1040, 133-141. [CrossRef]

6. Leonel, M.; do Carmo, E.L.; Fernandes, A.M.; Soratto, R.P.; Ebúrneo, J.A.M.; Garcia, E.L.; dos Santos, T.P.R. Chemical composition of potato tubers: The effect of cultivars and growth conditions. J. Food Sci. Technol. 2017, 54, 2372-2378. [CrossRef]

7. Xing, Y.; Niu, X.; Wang, N.; Jiang, W.; Gao, Y.; Wang, X. The correlation between soil nutrient and potato quality in Loess Plateau of China based on PLSR. Sustainability 2020, 12, 1588. [CrossRef]

8. Bulgari, R.; Franzoni, G.; Ferrante, A. Biostimulants application in horticultural crops under abiotic stress conditions. Agronomy 2019, 9, 306. [CrossRef]

9. Van Oosten, M.J.; Pepe, O.; De Pascale, S.; Silletti, S.; Maggio, A. The role of biostimulants and bioeffectors as alleviators of abiotic stress in crop plants. Chem. Biol. Technol. Agric. 2017, 4, 5. [CrossRef]

10. Drobek, M.; Frac, M.; Cybulska, J. Plant biostimulants: Importance of the quality and yield of horticultural crops and the improvement of plant tolerance to abiotic stress-A review. Agronomy 2019, 9, 335. [CrossRef]

11. Sharma, H.S.S.; Fleming, C.; Selby, C.; Rao, J.R.; Martin, T. Plant biostimulants: A review on the processing of macroalgae and use of extracts for crop management to reduce abiotic and biotic stresses. J. Appl. Phycol. 2014, 26, 465-490. [CrossRef]

12. Battacharyya, D.; Babgohari, M.Z.; Rathor, P.; Prithiviraj, B. Seaweed extracts as biostimulants in horticulture. Sci. Hort. 2015, 196, 39-48. [CrossRef]

13. Begum, M.; Bordoloi, B.C.; Singha, D.D.; Ojha, N.J. Role of seaweed extract on growth, yield and quality of some agricultural crops: A review. Agric. Rev. 2018, 39, 321-326. [CrossRef]

14. Shukla, P.S.; Mantin, E.G.; Adil, M.; Bajpai, S.; Critchley, A.T.; Prithiviraj, B. Ascophyllum nodosum-Based biostimulants: Sustainable applications in agriculture for the stimulation of plant growth, stress tolarance, and disease management. Front. Plant. Sci. 2019, 10, 655. [CrossRef] [PubMed]

15. De Saeger, J.; Van Praet, S.; Vereecke, D.; Park, J.; Jacques, S.; Han, T.; Depuydt, S. Toward the molecular understanding of the action mechanism of Ascophyllun nodosum extracts on plants. J. Appl. Phycol. 2020, 32, 573-597. [CrossRef]

16. Strick, W.A.; Tarkowská, D.; Turečová, V.; Strnad, M.; van Staden, J. Abscisic acid, gibberellins and brassinosteroids in $\operatorname{Kelpak}^{\circledR}$, a commercial seaweed extract made from Ecklonia maxima. J. Plant. Phycol. 2014, 26, 561-567. [CrossRef]

17. Lötze, E.; Hoffman, E.W. Nutrient composition and content of various biological active compounds of three South African-based commercial seaweed biostimulants. J. Appl. Phycol. 2016, 28, 1379-1386. [CrossRef]

18. Al-Bayaty, H.J.M.; Al-Quraishi, G.M.A. Response of three potato varieties to seaweed extract. Kufa J. Agric. Sci. 2019, 11, 36-48.

19. Grześkiewicz, H.; Trawczyński, C. Foliar application of compound fertilizers in the potato cultivation. Folia Univ. Agric. Stetin. 1998, 190, 75-80. (In Polish)

20. Wierzbowska, J.; Cwalina-Ambroziak, B.; Głosek, M.; Sienkiewicz, S. Effect of biostimulators on yield and selected chemical properties of potato tubers. J. Elem. 2015, 20, 757-768. [CrossRef]

21. Haider, M.W.; Ayyub, C.M.; Pervez, M.A.; Asad, H.U.; Manan, A.; Raza, S.A.; Ashraf, I. Impact of foliar application of seaweed extract on growth, yield and quality of potato (Solanum tuberosum L.). Soil Environ. 2012, 31, 157-162.

22. Kwiatkowski, C.; Kołodziej, B.; Woźniak, A. Yield and quality of carrot (Daucus carota L.) roots depending on growth stimulators and stubble crops. Acta Sci. Pol. Hortorum Cultus 2013, 12, 55-68.

23. Erlichowski, T. Effect of plant growth regulators on quality and yielding of potato. Progr. Plant. Prot. Post. Ochr. Roślin 2005, 45, 645-649. (In Polish)

24. Pobereżny, J.; Szczepanek, M.; Wszelaczyńska, E.; Prus, P. The quality of carrot after biostimulant application and after storage. Sustainability 2020, 12, 1386. [CrossRef]

25. Kocira, A.; Lamorska, J.; Kornas, R.; Nowosad, N.; Tomaszewska, M.; Leszczyńska, D.; Kozłowicz, K.; Tabor, S. Changes in biochemistry and yield response to biostimulants applied in bean (Phaseolus vulgaris L.). Agronomy 2020, 10, 189. [CrossRef] 
26. Matysiak, K.; Kaczmarek, S.; Kierzek, R. Effect of algae Ecklonia maxima (Kelpak SL) on winter oilseed rape. Rośliny oleiste Oilseed Crops 2012, 33, 82-88. (In Polish)

27. Matysiak, K.; Kaczmarek, S.; Leszczyńska, D. Influence of liquid seaweed extract of Ecklonia maxima on winter wheat cv. Tonacja. J. Res. Appl. Agric. Engng. 2012, 57, 44-47.

28. Canellas, L.P.; Olivares, F.L. Physiological responses to humic substances as plant growth promoter. Chem. Biol. Technol. Agric. 2014, 1, 3. [CrossRef]

29. Canellas, L.P.; Olivares, F.L.; Aguiar, N.O.; Jones, D.L.; Nebbioso, N.; Mazzei, P.; Piccolo, A. Humic and fulvic acids as biostimulants in horticulture. Sci. Hort. 2015, 196, 15-27. [CrossRef]

30. Yu, Z.; Ruonan, W.; Xiaoqian, Q.; Jinshui, Y.; Baozhen, L.; Hongli, Y. Effects of biostimulant humic acid on physiological metabolism of plant. Humic Acid 2019, 3, 1-6.

31. Conselvan, G.B.; Pizzeghello, D.; Francioso, O.; Di Foggia, M.; Nardi, S.; Carletti, P. Biostimulant activity of humic substances extracted from leonardities. Plant. Soil 2017, 420, 119-134. [CrossRef]

32. Selim, E.M.; Mosa, A.A.; El-Ghamry, A.M. Evaluation of humic substances fertigation through surface and subsurface drip irrigation systems on potato growth under Egyptian sandy soli conditions. Agric. Water Manag. 2009, 96, 1218-1222. [CrossRef]

33. Alenazi, M.; Wahb-Allah, M.A.; Abdel-Razzak, H.S.; Ibrahim, A.A.; Alsadon, A. Water regimes and humic acid application influences potato growth, yield, tuber quality and water use efficiency. Am. J. Potato Res. 2016, 93, 463-473. [CrossRef]

34. Ekin, Z. Integrated use of humic acid and plant growth promoting rhizobacteria to ensure higher potato productivity in sustainable agriculture. Sustainability 2019, 11, 3417. [CrossRef]

35. Suh, H.Y.; Yoo, K.S.; Suh, S.G. Tuber growth and quality of potato (Solanum tuberosum L.) as affected by foliar or soil application of fulvic and humic acids. Hort. Environ. Biotechnol. 2014, 55, 183-189. [CrossRef]

36. Dobrzański, A.; Anyszka, Z.; Elkner, K. Response of carrots to applicationof natural extracts from seaweed (Saragassum sp.)—Algaminoplant and from leonardite-HumiPlant. J. Res. Appl. Agric. Engng. 2008, 53, 53-58.

37. Karakurt, Y.; Unlu, H.; Unlu, H.; Padem, H. The influence of foliar and soil fertilization of humic acid on yield and quality of pepper. Acta Agric. Scand. B-PS 2009, 59, 233-237. [CrossRef]

38. Ozdamar Unlu, H.; Unlu, H.; Karakurt, Y.; Padem, H. Changes in fruit yield and quality in response to foliar and soil humic acid application in cucumber. Sci. Res. Essays 2011, 6, 2800-2803.

39. Husein, M.E.; Abou El Hassan, S.; Shahein, M.M. Effect of humic, fulvic acid and calcium foliar application on growth and yield of tomato plants. Int. J. Biosci. 2015, 7, 132-140. [CrossRef]

40. Skowera, B. Changes of hydrothermal conditions in the Polish area (1971-2010). Fragm. Agron. 2014, 31, 74-87. (In Polish)

41. Polish Standard PN-ISO 10390:1997. Soil Quality_Determination of $p H$; Polish Committee for Standardization: Warsaw, Poland, 1997. (In Polish)

42. Polish Standard PN-ISO 11261:2002. Soil Quality—Determination of Total Nitrogen—Modified Kjeldahl Method; Polish Committee for Standardization: Warsaw, Poland, 2002. (In Polish)

43. Polish Standard PN-R-04023:1996. Chemical-Agricultural Analysis of Soil-Determination of Available Phosphorus in Mineral Soils; Polish Committee for Standardization: Warsaw, Poland, 1996. (In Polish)

44. Polish Standard PN-R-04022:1996+Az1:2002. Chemical-Agricultural Analysis of Soil_Determination of Available Potassium in Mineral Soils; Polish Committee for Standardization: Warsaw, Poland, 2002. (In Polish)

45. Polish Standard PN-R-04020:1994+Az1:2004. Chemical-Agricultural Analysis of Soil_Determination of Available Magnesium; Polish Committee for Standardization: Warsaw, Poland, 2004. (In Polish)

46. Nowacki, W. Characteristic of Native Potato Cultivars Register, XXII ed.; Plant Breeding Acclimatization Institute-National Research Institute: Section Jadwisin, Poland, 2019; pp. 1-43.

47. Meier, U. Growth Stages of Mono- and Dicotyledonous plants: BBCH Monograph; Open Agrar Repositorium: Quedlinburg, Germany, 2018; pp. 1-204.

48. Polish Standard PN-EN 12145:2001P. Fruit and Vegetable Juices_Determination of Total Dry Matter-Gravimetric Method with Loss of Mass on Drying; Polish Committee for Standardization: Warsaw, Poland, 2001. (In Polish)

49. Polish Standard PN-EN ISO 10520:2002. Native Starch-Determination of Starch Content_Ewers Polarimetric Method; Polish Committee for Standardization: Warsaw, Poland, 2002. (In Polish)

50. Polish Standard PN-A-79011:1998. Dry Food Mixes_Test Methods_Determination of Sugar Content; Polish Committee for Standardization: Warsaw, Poland, 1998. (In Polish) 
51. Polish Standard PN-A-04018:1975/Az3:2002. Agricultural Food Products—Determination of Nitrogen by Kjeldahl Method and Expressing in Protein; Polish Committee for Standardization: Warsaw, Poland, 2002. (In Polish)

52. Polish Standard PN-A-04019:1998. Food Products—Determination of Vitamin C Content; Polish Committee for Standardization: Warsaw, Poland, 1998. (In Polish)

53. International Standard ISO 6635:1984. Fruits, Vegetables and Derived Products-Determination of Nitrite and Nitrate Content-Molecular Absorption Spectrometric Method; International Organization for Standardization: Geneva, Switzerland, 1984.

54. Pokluda, R. An assessment of the nutritional value of vegetables using an ascorbate-nitrate index. Veget. Crops. Res. Bull. 2006, 64, 29-37.

55. Roztropowicz, S. Methodology of Observation, Measurements and Sampling in Agronomic Experiments with Potatoes; Plant Breeding and Acclimatization Institute: Section Jadwisin, Poland, 1999; pp. 1-50. (In Polish)

56. Sawicka, B.; Michałek, W.; Pszczółkowski, P. The relationship of potato tubers chemical composition with selected physiological indicators. Zemdirb. -Agric. 2015, 102, 41-50. [CrossRef]

57. Wadas, W.; Dziugieł, T. Changes in assimilation area and chlorophyll content of very early potato (Solanum tuberosum L.) cultivars as influenced by biostimulants. Agronomy 2020, 10, 387. [CrossRef]

58. Rogozińska, I.; Pawelzik, E.; Pobereżny, J.; Delgato, E. The effect of different factors on the content of nitrate on some potato varieties. Potato Res. 2005, 48, 167-180. [CrossRef]

59. Trawczyński, C.; Wierzbicka, A. Relationship between vitamin C and nitrates contents in tubers of potato cultivars belonging to different maturity groups. Biul. IHAR 2012, 266, 143-150. (In Polish)

60. Wang-Pruski, G.; Nowak, J. Potato after-cooking darkening. Am. J. Potato Res. 2004, 81, 7-16. [CrossRef]

61. Wadas, W.; Dziugiel, T. Growth and marketable potato (Solanum tuberosum L.) tuber yield in response to foliar application of seaweed extract and humic acids. Appl. Ecol. Environ. Res. 2019, 17, 13219-13230. [CrossRef]

(C) 2020 by the authors. Licensee MDPI, Basel, Switzerland. This article is an open access article distributed under the terms and conditions of the Creative Commons Attribution (CC BY) license (http://creativecommons.org/licenses/by/4.0/). 